\title{
Pūpūkahi i Holomua: A Story of Hawaiian Education and a Theory of Change
}

Keali'i Kukahiko

Office of Hawaiian Education

\& UH Mānoa Ethnic Studies Dept.

Pono Fernandez

Office of Hawaiian Education

Dawn Kau'i Sang

Office of Hawaiian Education

\section{Kamuela Yim}

Office of Hawaiian Education

\section{Anela Iwane}

Office of Hawaiian Education

Ka'anohiokalā Kalama-Macomber Office of Hawaiian Education
Ku'ulei Makua

Office of Hawaiian Education

Karen Nakasone

Office of Hawaiian Education

Dana Tanigawa

Office of Hawaiian Education

Kāhea Kim

Office of Hawaiian Education

Leinā'ala Cosma Reyes

Office of Hawaiian Education

Tristan Fleming-Nazara

UH Mānoa Undergraduate Researcher

\section{Abstract}

The Hawaiian kingdom, prior to the illegal overthrow of its monarchy (1893) and the subsequent English-only Law (1896), had boasted a 91-95\% literacy rate. Within that learning environment learners had a clear sense of purpose because Hawaiians had a

ISSN 2560-8371

DOI: 10.24908/encounters.v21i0.14218

c) Encounters in Theory and History of Education | 175 
firm grasp of who they were, where they were, and what they had to contribute. Since the English-only Law and US annexation of Hawai'i (1898), however, the settler colonialschool system has maintained levels of cultural dissonance that have manifested as inequitable student outcomes for Native Hawaiians and Pacific Islanders (NHPI) across multiple academic and disciplinary student indicators (i.e., proficiency, suspension rates, etc). While western law and US compulsory education severed traditional sources of knowledge production that had provided a sustainable model of a'o (teaching and learning), the ancestors of the Native Hawaiian community were diligent about preserving the keys to their genealogical legacies within more than 120,000 pages of Hawaiian-language newspapers. This collective repository is a resource that helps the Office of Hawaian Education (OHE) rethread Hawaiian education into the tapestry of traditional sources of knowledge production to improve sustainability (cultural, intellectual, environmental, political, etc.) for all learners. OHE uses a theory of change that engages primary and secondary sources, quantitative and qualitative data, in action research that informs Why contemporary circumstances exist, What those contemporary circumstances are, Where we want Hawaiian education to go, and How we are going to get there.

Keywords: cultural dissonance, activist research, ontological self-efficacy, interest convergence, culturally responsive educational $\mathrm{P} 4$

\section{Pūpūkahi i Holomua : Une histoire de l'éducation hawaïenne et une théorie du changement}

\section{Résumé}

Avant le renversement illégal de sa monarchie (1893) puis la loi «English-only » (1896) instaurant l'anglais comme langue officielle unique, le royaume d'Hawaï affichait un taux d'alphabétisation de 91 à $95 \%$. Au sein de cet environnement d'apprentissage, les apprenants avaient un objectif clair, car les Hawaïens savaient parfaitement qui ils étaient, où ils étaient et ce qu'ils devaient apporter à la communauté. Depuis la loi « English-only » puis l'annexion de Hawa'i (1898) par les États-Unis, cependant, le système scolaire colonial a entretenu des niveaux de dissonance culturelle qui se sont manifestés par des résultats inéquitables pour les élèves autochtones de Hawaï et des îles du Pacifique (Native Hawaiians and Pacific Islanders, NHPI) selon de multiples indicateurs scolaires et disciplinaires (compétence, taux d'exclusion, etc.) Tandis que le droit occidental et l'instruction américaine obligatoire supprimaient les sources traditionnelles de production de connaissances qui avaient fourni un modèle durable d'a'o (enseignement et apprentissage), les ancêtres de la communauté autochtone hawaïenne ont pris soin de préserver les clefs de leur héritage généalogique dans plus 
de 120000 pages de journaux en langue hawaïenne. Ce fonds collectif est une ressource précieuse qui aide le Bureau hawaïen de l'éduction (Office of Hawaiian Education, $\mathrm{OHE}$ ) à réinsérer l'éducation hawaïenne dans le tissu des sources traditionnelles de production de connaissances afin d'accroître leur durabilité (culturelle, intellectuelle, environnementale, politique, etc.) pour tous les élèves. L'OHE s'appuie sur une théorie du changement qui fait appel à des sources primaires et secondaires, à des données quantitatives et qualitatives, à une recherche-action qui permet de comprendre pourquoi les circonstances actuelles sont telles qu'elles sont, quelles sont ces circonstances actuelles, où nous voulons voir aboutir l'éducation hawaïenne et comment nous allons y parvenir.

Mots-clés: dissonance culturelle, recherche-action, auto-efficacité ontologique, convergence d'intérêts, P4 éducatifs culturellement adaptés

\section{Pūpūkahi i Holomua: Una historia de la educación hawaiana y una teoría del cambio}

\section{Resumen}

El Reino de Hawái, antes del derrocamiento ilegal de su monarquía (1893) y la subsiguiente Ley de solo inglés (1896), había contado con un nivel de alfabetización de entre $91-95 \%$. Dentro de ese ambiente de aprendizaje, los que aprendían tenían un claro sentido de propósito porque los hawaianos tenían un entendimiento sólido de quiénes eran, dónde estaban y lo que tenían para contribuir. Desde la Ley de solo inglés y la anexión estadounidense de Hawái (1898), empero, el sistema escolar colonizador ha mantenido unos niveles de discordancia cultural que se han manifestado como un rendimiento estudiantil no equitativo para hawaianos nativos e isleños del Pacífico (NHPI, por sus siglas en inglés) a través de múltiples indicadores estudiantiles académicos y por disciplina (i.e., proficiencia, porcentaje de suspensión, etc.). Mientras que la ley occidental y la educación compulsoria estadounidense rompieron con fuentes tradicionales de producción de conocimiento que habían proveído un modelo sostenible de a'o (enseñanza y aprendizaje), los antepasados de la comunidad hawaiana nativa se esmeraron por preservar las llaves a sus legados genealógicos con más de 120,000 páginas de periódicos en lengua hawaiana. Este depósito colectivo es un recurso que ayuda a la Oficina de educación hawaiana (OHE, por sus siglas en inglés) a rehacer la educación hawaiana como material de fuentes tradicionales de producción de conocimiento para mejorar la sostenibilidad (cultural, intelectual, modioambiental, política, etc.) para todos los que aprenden. OHE utiliza una teoría del cambio que usa fuentes primarias y secundarias, datos cualitativos y cuantitativos en investigación para la acción que informa por qué existen las 
circunstancias actuales, cuáles son esas circunstancias contemporáneas, a dónde queremos que se dirija la educación hawaiana y cómo vamos a llegar allí. Palabras clave: discordancia cultural, investigación activista, autoeficacia ontológica, convergencia de intereses, P4 educacional culturalmente sensible

\section{Introduction}

Today, only $35 \%$ of NHPI students in HIDOE meet proficiency standards in Language Arts, while only $25 \%$ are "proficient" in Mathematics. This is a significant drop from the 91-95\% literacy rate of the Hawaiian kingdom, prior to the illegal overthrow of its monarchy in 1893, and the subsequent English Only Law of 1896. NHPI students in HIDOE also maintain the highest rates of suspension, the largest gap in college aspiration:participation, an active and sustained over-representation in the school to prison pipeline, and the highest rates of suicide and suicide attempts in the US. The Office of Hawaiian Education (OHE) hypothesized that low performing NHPI student outcome data were manifestations of cultural dissonance, which studies suggest are a natural byproduct of US compulsory education (Lomawaima \& McCarty, 2002; Wright \& Balutski, 2016). There were two phases to the historical investigation. The primary source investigation sought to understand the process of a'o (teaching and learning) before US compulsory education, a process that seemed to have provided learners a clear sense of purpose, a firm grasp of who they were, where they were, and what they had to contribute. The second phase of the historical investigation sought to understand how the events, processes and systems that severed Hawaiian education from traditional sources of knowledge production. These collective findings were able to contextualize the contemporary circumstances that create the student outcome data that OHE had found within the Hawai'i Department of Education (HIDOE). The OHE Theory of Change is used to inform educational P4 (practices, projects, programs and policies) that recalibrate contemporary circumstances of Hawaiian education towards a desired futurity.

\section{Context of an Unsustainable Model of Education in Hawai' $i$}

Today, Hawai'i currently exists within a specialized economy whose major industries outside of the state public sector are tourism, construction and the military. Since careers in these major industries do not require college degrees, the current success of $\mathrm{K}-12$ education in Hawai' $\mathrm{i}$ can be measured by its ability to move local students out of the islands and into the diaspora, creating "brain drain." This diasporic movement causes the continual attrition of potential leadership and political capital as they pertain to local politics, and resistance to foreign encroachment, which continues to take form in the dispossession of land. ${ }^{1}$ The combination of the specialized economy and the 
high cost of living makes the return home for many Native Hawaiians (who live in the diaspora) financially unattainable. This form of local "brain drain" is a cyclical and systemic problem in Hawai' $i$, which also reflects (or reproduces) the unsustainable nature of its economic dependence on foreign interests, and is in part due to the failure of US compulsory education as it is applied in Hawai'i. When educational curriculum in Hawai' $i$ is disconnected from student identities - their strengths, sense of place, culture - learned knowledge is no longer relevant to this specific place of learning, or the sustenance of this place, and the original intent of the compulsory education system is maintained by the educational pipeline that extracts valuable cultural, intellectual and political resources. This is an unsustainable model of education for Hawai' $i$ that moves academically "successful" students into the diaspora as consumers of US intellectual goods, or "unsuccessful" students into its restrictive specialized economy.

\section{OHE Theory of Change}

The OHE Theory of Change is a map key, or legend, meant to help stakeholders of Hawaiian education navigate its colonial history and contemporary circumstances, and recalibrate its course towards a decolonized futurity. The collective global experiences of colonization provide both predictive and interpretive qualities to this framework (Alfred, 2009). Often these colonial mechanisms (processes) and strategies (systems) are introduced to Indigenous peoples to "reshape," "negotiate" or improve upon "unsophisticated" societies, until colonization transfers power and control to the usurper, at which time, those colonial processes and systems collectively operate to annihilate, erase and replace their indigenous counterparts (Goodyear-Ka'ōpua, 2013; Trask, 1999). This colonial shift transforms indigenous societies in accordance with an intentional imperial agenda, preparing Indigenous societies for occupation by disempowering, disenfranchising and deconstructing Indigenous knowledge systems.

\section{Ontological Frameworks}

OHE has appropriated the terms ontology, axiology, methodology, and epistemology in the identification of knowledge production systems that have characterized Hawaiian education. ${ }^{2}$ While ontology is often referred to as the nature of being, rather than a way of knowing, the OHE ontological framework describes a process that transition learners from consumers of knowledge to knowledge producers, a process which enables them to either maintain reality as a state of being, or change reality to manifest a state of being that better align with their own frames of reference (axiology, methodology, epistemology). In the OHE Theory of Change, there are three components of an ontological framework: (1) Axiology are the morals and values that dictate how we 
interact with our reality; (2) Methodology are the methods (and the reasons behind them) of collecting data that inform our reality; (3) Epistemology is what we "know" about reality, which we actively change or maintain through action and inaction. OHE defines an ontological framework as the collective components and processes of knowledge production that operationalize culture, in the construction and maintenance of a reality that either serves the needs of its diversified members, or the needs of a hegemonic few.

In an "open" ontological framework each component informs one another to constantly produce new knowledge and empower learning communities to actualize a desired reality. In a "closed" ontological framework, objectivity is a standard of dehumanization that dissociates the three components of the ontological framework to restrict knowledge production, and thereby, creates a singular narrative from a singular perspective, which is disseminated by a dominant politics of knowledge through compulsory education. This academic process creates knowledge consumers who matriculate from US compulsory education and embed the disorientation of a "closed" ontological framework into the current reality when they participate in work that misaligns with their axiology, methodology and/or epistemology. This unsustainable model of education reproduces unsustainable realities that force Indigenous peoples to survive within environments of "disassociation," where they are often measured by lagging outcome indicators such as achievement gaps, school to prison pipelines, college participation, etc. The OHE Theory of Change predicts that "closed" ontological frameworks become "open" when a critical mass is reconnected to traditional sources of knowledge production and develop ontological self-efficacy. Ontological self-efficacy is the liberation from intellectual dependence and represents the transition from knowledge consumption to knowledge production, which empowers learners to actualize alternative realities of their own making.

\section{Hawaiian Constellation Methodology of Navigation}

\section{Indigenous Methodology}

Indigenous methodologies address the politics and strategic goals of the researcher, while the methods become the "means and procedures through which the central problems of the research are addressed" (Smith, 1999, p. 143). In this way, the specific challenges and nuances that have become the collective experiences of colonized peoples, can be used as a predictive framework in the research design of studies that involve Indigenous populations (Alfred, 2009). What Smith (1999) makes clear in her Twenty-five Indigenous Projects, is that the application of Indigenous methodologies should be intentional and purposeful, grounded in cultural knowledge and practices, but also operationalized through its specific methods, and therefore, replicable. Ontological self-efficacy is a liberatory process of education modeled by Indigenous 
peoples who "conduct quality scholarly research utilizing innovative ways of inquiry that align with Indigenous worldviews" (Kahakalau, 2019, p. 12). Using the traditional methodology of navigation as a model, the constellation method is an indigenous evaluative methodology that Puni Jackson designed in her work with Ho'oulu 'Āina, an OHE community partner. Ulu hōkū are constellations, the pivotal star maps that guided Kanaka Maoli ancestors through the expanse of the ocean towards their island homes. The design of the Ulu hōkū (constellation) report demonstrates the connectivity between elements of the work and the foundational principles that guide OHE. This constellation methodology centers around the single navigational star and the "shape of the sky" surrounding it. Pualani Lincoln, a student of Shorty Bertleman (the navigator for the latest voyage to Mokumanamana on Makali i i), shared with OHE staff how an intimate relationship with the stars in the sky develop over time and with intent, helping navigators plot their course across Oceania. A single star serves as the marker for a destination. At times through the night, though, that star may not be visible in the sky. Knowing the shape of the sky, the constellations and the stars surrounding the navigational star allow the navigator to know where that star is at all times of the night.

\section{Application of Constellation Methodology of Navigation to OHE's Work}

While many institutions are driven by political platforms that address lagging indicators (i.e., achievement gap, absenteeism, suspension rates, etc.), without historical context these responses are often reactionary and only treat the symptoms of larger systemic issues. The OHE Theory of Change uses a traditional Hawaiian constellation methodology of navigation as a cultural construct that requires three points of reference to triangulate data that inform the "change" process: constellation of origin (historical context), current position (contemporary circumstances) and a desired destination (futurity). Once these three points of reference are established, OHE is able to use historical context to understand: (1) WHY the contemporary circumstances that create negative student outcomes exist, (2) WHAT the root issues of the contemporary circumstances are, (3) WHERE we want Hawaiian education to go, and (4) HOW we are going to get there. In this way, OHE constellates their praxis by using the historical context and informed futurity to identify educational P4 (practices, projects and policies) that can recalibrate contemporary circumstances and realign the course of Hawaiian education towards its desired futurity. OHE's Theory of Change predicts that transformational shifts in education can occur when P4 is bonded to events and policies that create interest convergence.

\section{Mixed Methods}

With a Hawaiian Constellation Methodology of Navigation guiding the research methods (i.e., data collection, data analysis and storytelling), OHE looks towards Kahiki, voyaging towards an education system rooted in 'ike kupuna and aloha 'āina. 
Guided by that star, the shape of the surrounding sky will tell us whether or not we are on track. Through qualitative and quantitative data, our communities will be able to map their work to outcomes grounded in Hawaiian ways of knowing, and inform the P4 that helps guide the entire system towards Kahiki. This connectivity speaks to multiplicity of mo'olelo and collective impact, implying that different data elements come together to tell the complete story of the depth and breadth of the work. The methodology for this research is a mixed methods exploratory design in which the qualitative and quantitative strands are implemented in a sequence (Creswell \& Park, 2011). The qualitative methods will occur first and will have a greater emphasis in addressing the study's purpose, and the quantitative methods will follow to assess the extent to which the initial qualitative findings generalize to the NHPI student population. While the description of the mixed methods herein use academic vernacular, our "hope is that it will inspire the next generations of Indigenous researchers, in Hawai'i and beyond, to create new, culturally driven research methodologies, aligned with native worldviews and designed to advance native people, protect our land, and perpetuate our languages and cultures" (Kahakalau, 2019, p. 1).

\section{The Desired Futurity for Hawaiian Education}

OHE's historical investigation places the kahiki of Hawaiian education as one that exists within a sustainable model of education through strength, place and culturebased pedagogies, with the capacity to actualize a healthier, more equitable, empathetic, innovative and sustainable Hawai' $i$. "Futurities are ways that groups imagine and produce knowledge about futures; thus futurities shape the horizons of possibility for specific futures" (Goodyear-Ka'ōpua, \& Kuwada, 2018, p. 2). While the means and the pathway to realize a futurity may change in response to the environment, or unforeseen calamities and events, the origin and the destination remain the same. When education in Hawai' $i$ loses its sense of direction, the three points of reference (historical context, contemporary circumstances and futurity) enable stakeholders to reorient and realign initiatives in response to COVID-like crises and events, to pūpūkahi i holomua. By centering mo'olelo, finding interest convergence, and continuously checking for $H \bar{A}$ (BREATH) indicators ${ }^{3}$ within learning environments, OHE remains agile and flexible in the design of educational P4 that reorient, recalibrate and realign learning conditions that correct 
for educational "drift," or the deviation of Hawaiian education from a period that boasted a 91-95\% literacy rate. The OHE Theory of Change uses four tenets to identify its four constellations: the historical context explains WHY the contemporary circumstances exist and WHAT the root issues are that have manifested as a result of educational "drift," and collectively, interest convergence and educational P4 are HOW Hawaiian education reaches its desired futurity (or the WHERE).

The desired futurity for Hawaiian education exists within a sustainable model of a'o that engages learners as knowledge producers with strength, place and culturebased pedagogies that reconnect them to traditional sources of knowledge production. The arrival at this futurity is marked by the mastery of a student's contribution, the internalization of kuleana to serve the collective interests of kaiāulu, and the constellation of a healthier, more equitable, empathetic, innovative and sustainable Hawai'i.

\section{Tenet 1: Use Historical Investigation to Identify WHY Contemporary} Circumstances Exist

\section{Primary Source Historical Investigation}

Why the story of Kekūhaupi'o. Kekūhaupi'o was a famous warrior, but perhaps an even greater teacher. His mo'olelo is told from the perspectives of both a student, and the teacher of King Kamehameha in the art of war. ${ }^{4}$ His mo'olelo - first written by Samuel Manaiakalani Kamakau ${ }^{5}$ in a Hawaiian language newspaper - provides the perfect lens to understand the Hawaiian ontological framework, and how it influenced the process of a'o. Kamakau was born in 1815, and before passing in 1876, had served as a legislator, educator and judge, and therefore, stood at the precipice between two worlds. He was a product of a literacy movement in Hawai' $i$ that boasted a $91-95 \%$ literacy rate, and participated in an era of Hawaiian education that embedded and nurtured traditional sources of knowledge production, which yielded a generation of kanaka with the skills to negotiate western law; a generation who worked to sustain a reality aligned to a Hawaiian ontological framework. The analysis herein will identify stars that form a constellation over an original reference point, which preceded the educational drift of Hawaiian education that deviated its course towards contemporary circumstances.

Constant Comparative Analysis. This was a primary document analysis using three techniques within a constant comparative analysis (Creswell, 2003). ${ }^{6}$ During open coding, or the initial stage of organizing the data, the mo'olelo was categorized into the three components of an ontological framework: axiology, methodology, and epistemology. Through axial coding, or the interconnecting of categories, the pieces 
of mo'olelo were placed into three educational categories: 'ike ma'i'o (knowledge content), nā hailona, nā ho'ike a me nā hopena (tests, assessments and outcomes), and 'ano $o$ a'o (characteristics of a'o). During the selective coding process, the analysis attempted to understand whether specific characteristics of the Hawaiian ontological framework were intentionally integrated into the process of a'o in a predictive manner. By using 'ōlelo no'eau' (proverbs that reflect Hawaiian ontological framework), the researchers were able to triangulate the intentionality of specific P4 (practices, projects, programs and policies) within the individual educational categories (knowledge content, tests/assessments/outcomes, characteristics of a'o). This analysis will give us a better understanding of how the components of a Hawaiian ontological framework inform each other within the a'o process, and identify specific P4 that can be replicated today to reconnect students to traditional sources of knowledge production, and thereby, create an "open" ontological framework for contemporary Hawaiian education.

A Historical Example of A'o and A Hawaiian Ontological Framework. The first finding in the constant comparative analysis was that Hawaiian education before US compulsory education used an open ontological framework that allowed the process of a'o to be informed by all of its components: axiology, methodology and epistemology (As defined in the OHE Theory of Change). During the open coding process the mo'olelo was color-coded to represent axiology, methodology and epistemology, and during the axial coding process it was visually clear that the three components of an open ontological framework had informed the a'o process. The second finding was that educational content was always aligned to components of student identity based on an assessment of the student's strengths and readiness. Five content categories were created to accommodate the qualitative data collected in the mo'olelo: 'âina, kūpuna, nā pilina, ea and 'aha. See Appendix A (Coding Guidelines for 'Ike Ma'i'o) and Appendix B (The application of 'Ike Ma'i'o to Design of Educational P4).

The third finding was that student assessments did not measure singular literacies with one-dimensional outcomes, but rather the educational content represented delivery mechanisms for social values; thus, proficiency and competency were measured by the student's ability to display those social values in the application of content knowledge. Kohapiolani (father) and Koaia (the lua instructor) provide examples of this in the mo'olelo, when they insist that the success of Kekūhaupi'o will not be measured in his ability to use the art of war to harm and oppress others, but in the protection of lāhui and in service of his haku (lord). At the end of his time with the lua instructor, Kekūhaupi'o had three tests, one for courage and two for cleverness. The first was for Kekūhaupi'o to kill and eat the eye of the niuhi shark (man-eating tiger shark). This test had nothing to do with the lua skills that he had learned, but everything to do with having patience in assessing new and unfamiliar contexts, while acting decisively with a confidence developed through preparation (courage). The other two tests were sparring matches designed for Kekūhaupi'o to overcome unfamiliar 
challenges through his adaptation of learned skills, or using creativity to imagine and produce new knowledge (cleverness). His success then, depended on an open ontological framework that required him to create new knowledge. The societal values found within the mo'olelo represent intended outcomes that were modeled by kumu (teachers) - thereby, setting the conditions for learning - and provide the six categories of nā hailona, nā ho'ike a me nā hopena (tests, assessments and outcomes): belonging, responsibility, excellence, aloha, total well-being and Hawai'i (BREATH). Table 2 below represents the Coding Guidelines for tests, assessments and outcomes. See Appendix C (Coding Guidelines for nā hailona, nā ho'ike a me nā hopena) and Appendix D (Description of $\mathrm{HA}$ Indicators).

The fourth finding was that there were four major characteristics of a'o that were shared by both teachers and learners: nalu, hana, mālama, and 'auamo. Nalu is the observation, reflection and recognition of a desired learning outcome. Hana means work, and represents the transition from recognition to action, or application of knowledge. Mālama means to care for, and characterizes the steps that teachers and learners take to create multiple supports and sources for learning. 'Auamo is a stick used to carry burdens, and represents the internalization of responsibility for the mastery of their craft. Within these four characteristics there were eight specific functions (See Appendix E and Appendix F for Coding Guidelines for Nā 'Ano o ke A'o 'ana ): 1) normalize active kilo or nalu, 2) the creative application of 'ike ma'i'o, 3) remove doubt through preparation and trust in the process and work of a'o, 4) continue developing depth of knowledge, 5) extend learning to and from the home, 6) collaborative a'o, 7) empower teachers and learners to develop and fulfill sense of kuleana, and 8) develop scaffolding or agency to create readiness.

OHE researchers recognize the four stars (major characteristics) of nalu, hana, mālama and 'auamo as a constellation of sustainable a'o, but the eight specific examples coded from the story of Kekūhaupi'o represent a small sample of "best practices" found in the extensive repository of Hawaiian language newspapers. For example, Joseph Moku'ōhai Poepoe ${ }^{8}$ was concerned that kānaka might lose the knowledge of traditional Hawaiian navigation, and so he journaled his process of a'o in the Ka Na'i Aupuni Hawaiian language newspaper from September 25-28, 1906. Poepoe lamented that he was unable to capture all the knowledge required of mastery, but identified six characteristics of a'o within nalu, hana, mālama and 'auamo: 1) Ho'ona'auao (seeking of knowledge), 2) Ho'oma'ama'a (engage in practice), 3) Ho'opa'ana'au (build knowledge), 4) Ho'omana (exercise empowerment), 5) Ho'ā'o (apply and create knowledge), and 6) Hō'ike (demonstrate knowledge). If Hawaiian education is to be guided by the constellations of sustainable a'o, intention and context must also become stars within that constellation, or Hawaiian education might continue its educational drift. Perreira's (2013) work helps to explain how the components of a Hawaiian open-ontological framework (axiology, methodology and epistemology) inform one another, and defines the "intentionality" and context of our 
kūpuna (ancestors). 9 This means that Educational P4 (practices, projects, programs and policies) - that represents HOW stakeholders can be intentional about realignment to desired futurities and creating ideal conditions and characteristics of a'o (teaching and learning) - cannot resolve educational drift with culture-based content alone. Content without the appropriate intentionality and context,10 may not produce the desired learning outcomes without opportunities for teachers and learners to 'nalu, hana, mālama, and 'auamo.

\section{Second Phase of Historical Investigation}

The Severing of Traditional Hawaiian Sources of Knowledge Production. A history of "western" contact with Hawai'i is a mo'olelo told by many storytellers. Some were Christian missionaries, others were businessmen and lawyers, and occasionally there were those that occupied all three spheres of power and influence. These foreigners had various interests in Hawaiian politics, and generally the most simple narrative carried the greatest political influence. No single population, however, was more vested in the history, contemporary circumstances or future of Hawai' $i$ than its native peoples, but rarely has US history allowed Hawaiians to tell their own stories with their own voices. Those Native Hawaiians who survived the measles pandemic, who navigated the politics of Imperialism pre-annexation, who resisted the illegal overthrow of their monarchy, US annexation and eventual statehood are rarely quoted in US history textbooks despite 125,000 pages of primary historical source data in Hawaiian language newspapers. The erasure of Native Hawaiian narratives from the history of their own conquest reflects the deterioration of Hawaiian sustainability, selfdetermination and identity since the US set eyes on its fiftieth state.

Western Law. The enactment of Native Hawaiian ontological frameworks through language, cultural practices, etc. had enabled kanaka to access, improve upon, and pass on traditional sources of knowledge production and intellectual legacies. However, the imposition of western law in Hawai'i during the 1800's systematically erased 53 generations (Kauanui, 2008) of intellectual legacies from the formal institution of Hawaiian education; a system that once boasted a $91-95 \%$ literacy rate (Charlot, 2005). In 1819, the Breaking of Kapu ${ }^{11}$ was immediately followed by the arrival of the American Board of Commissioners for Foreign Missions (ABCFM) in 1820, and the Sumptuary Laws of 1825. These laws altered traditional morality and made Hawaiians dependent on foreigners to tell them what was pono. The sumptuary laws criminalized ordinary behavior like sex, 'awa, hula, surfing, etc. These and other laws including the Constitution of $1840,{ }^{12}$ the Mahele of $1848,{ }^{13}$ and the 1863 Law of Naming ${ }^{14}$ began to sever kanaka from their connections to 'āina, kūpuna, nā pilina, ea and 'aha (Osorio, 2002). As western law became the intermediary and executor of traditional Hawaiian sources of knowledge production, kanaka were increasingly removed from their intellectual and genealogical legacies. This "severing" created a 
dependence on an American colonial politics of knowledge, whose intellectual property continues to appreciate today with the inflation of tuition at both private and public institutions of education.

The Bayonet Constitution of 1887 , is another example in a series of legal events ${ }^{15}$ of the 1800's that demonstrated the power of deculturalization that western law wielded in the preparation of territories for colonial occupation. Prior to 1887, all races and ethnicities were welcome in Hawai $i$, and all were able to become naturalized citizens (Osorio, 2002). In 1887, however, a militia formed by white foreigners (called the Honolulu Riflemen) and backed by the US military, coerced King Kalākaua to sign a new constitution at rifle point. This document became known as the Bayonet Constitution of 1887, and gave US citizens and other non-Hawaiian nationals, who refused to become naturalized citizens of Hawai' $i$, the right to vote in Hawai'i. At the same time, the new constitution suppressed the Native Hawaiian electorate with rigorous property restrictions, and completely disenfranchised Asians as "aliens." This was the "first time that democratic rights had ever been determined by race in any Hawaiian constitution" (Osorio, 2002, p. 244). kanaka: Hawaiian people

kapu: prohibited, forbidden, sacred

pono: righteousness, balance

'awa: a ceremonial drink made from kava root

hula: traditional form of Hawaiian dance, storytelling and/or cultural protocol

‘āina: land

kupuna: ancestor or elder

(kūpuna denotes plural)

nā pilina: connections or relationships

ea: sovereignty or independence (cultural, intellectual, environmental, political, etc.)

'aha: cord, service for prayer and/or cultural protocol

The Bayonet Constitution of 1887, also made the Reciprocity Treaty of 1875 a permanent "agreement." Originally the "treaty" was a renewable treaty that allowed Hawai' $i$ to sell its sugar produce to the United States free of tariffs, and in exchange the US military's received a renewable lease for the exclusive use of "Pearl Harbor." After the Bayonet Constitution, however, the terms of the Reciprocity Treaty became permanent, and stipulated that the refinement of Hawaiian sugar cane must take place in California. By restricting the industrialization of Hawai' $i$, the United States saved itself from having to compete against its own colonial territory. This legislation set historical precedent for the US to exploit Hawai'i for its natural resources, while at the same time, expanding its consumers of finished goods.

Militarization of Hawai'i. The importance of a US military outpost in the Pacific set into motion a series of events that would prioritize foreign interests in Hawai' $i$ from the 19th century to today. During occupation, the US military has seized, exhausted, and destroyed natural resources in Hawai' $i$ in the interests of the "greater good," which has rarely included the social, cultural or political needs of Hawa'i or its Indigenous people. 
In 1929, the US military took their initial parcels of land in Makua for bombing and ammunition training (Kelly \& Quintal, 1977), and in 1965, Koho'olawe was the test site of three nuclear explosions, or

Wahi pana: legendary place

‘Āina: landp 1500 tons of TNT, by the US military. Both are wahi pana that are now uninhabitable. Ironically, indigenous resistance to military occupation was often met with nativist sentiments by colonial settlers, and military occupation has continued to permanently sever connections to wahi pana, and permanently sever the ability of those 'âina to feed the people of Hawai'i and participate in a sustainable future.

Tourism in Hawai'i. The marketing success of Hawaiian tourism often masks the issues of inequity and social injustice within the contemporary circumstances of Hawai' $i$ by perpetuating images of an island paradise, while erasing the historical contexts that have created them. While settler colonialists in positions of power recognize the importance of Hawaiian language and cultural practices in providing "authentic" tourist experiences, these experiences often occur within carefully manufactured exhibitions of cultural safaris that "role-play" Hawaiian culture in an exclusively historical context (Aikau, 2011; Trask, 2001); rather than a living and breathing culture that maintains social, cultural and political relevance in a contemporary context (Goodyear-Ka‘ōpua, 2013). By keeping Hawaiian cultural practices within a historical context, foreign interests can continue to evict Hawaiians from land and sacred spaces. One example includes Mauna o Wakea (or Mauna Kea), where Native Hawaiians protest the use of sacred land for the construction of large telescopes and are ridiculed as being "ignorant savages" who obstruct human progress and science (Casumbal-Salazar, 2017). Another example is the Kukahiko 'ohana in Makena on Maui island, where the family has been taxed out of beachfront property they have owned since 1883 (before the Overthrow), due to the high-cost of surrounding hotels and luxury condominiums. This process is driven by foreign land speculation and has created the highest cost of living in the US, pushing Native Hawaiians out of Hawai' $i$ and into the diaspora, further depoliticizing local issues and resistance against foreign interests.

Compulsory Education. When Kauikeaouli became king in 1824 he proclaimed to his people, "He aupuni palapala ko'u." When the written word He aupuni palapa ko'u: Mine is a nation of education was introduced to Hawai' $i$, it was embraced by the entire Hawaiian nation and kanaka learned to read in multigenerational learning environments. At this time, knowledge production was not restricted within school campuses or the four walls of its classrooms. In fact, learning and knowledge production had once been focused within the home and amongst family and neighbors. "The teachers were sent out into every village, into every home," said Kau'i Sai-Dudoit (Steele, 2016). Within a generation, the Hawaiian population boasted a 91$95 \%$ literacy rate (Charlot, 2005), and the publishing scene was vibrant. Within these 
learning environments, learners had a clear sense of purpose because Hawaiians had a firm grasp of who they were, where they were, and what they had to contribute; their learning reflected values and systems passed down from generation to generation. Kanaka were tethered to foundational values and mo'olelo that drove the work. However, the introduction of compulsory education - meant to further the US colonial agenda to bring Hawai'i into its union - significantly changed the landscape in which Hawaiian education had once existed.

After a white oligarchy overthrew the Hawaiian monarchy with the assistance of the US military in 1893, the usurpers lobbied the US for the annexation of Hawai'i despite the majority of Native Hawiians that opposed the resolution. The English-only law of 1896, however, established a compulsory education system responsible for the ongoing domestication and indoctrination of immigrants and indigenous peoples of Hawai'i. The law eliminated government funding for all Hawaiian medium schools, and their number dropped from 150 in 1880, to zero by 1902 (Lucas, 2020). This compulsory education has been complicit in spreading powerful pedagogies of erasure that have produced a society that is not only unequal, but largely blind to its own coloniality. "They enact the logic of elimination by suppressing Native histories and contemporary realities, by discounting Indigenous epistemologies and knowledge bases, and by individualizing and disciplining Native bodies" (Goodyear-Ka'ōpua, 2013, p. 25). The hegemonic nature of US compulsory education originates from its exclusive power over the politics of knowledge, which establishes a singular narrative, and a "closed" ontological framework.

\section{Tenet 2: Identify Cultural Dissonance within Student Outcome Data}

Defining the root issues, not its symptoms, was perhaps the most urgent task of this investigation. The research of OHE requires a historical inquiry to ensure that eugenic reasoning is not be used in the analyses of the student outcome data, and also the need to problematize economic advantage as a form of neo capitalist fatalism, which often positions the achievement gap and high-representation in the discipline data as natural outcomes of low socio-economic status (SES). This research positionality led OHE to identify the impact of Cultural Dissonance within the student outcome data. Cultural dissonance is the conflict caused by the inconsistencies between students' home culture and the campus culture (Jayakumar \& Museus, 2012), or "the tension students feel as a result of incongruence between their cultural meaning-makingsystems and new cultural information they encounter" (Museus \& Quaye, 2009, p. 81). 
Native Hawaiian and Samoan junior high school student in HIDOE: "I want to live in O'okala. I love it here, and I don't want to live anywhere else. Nothing this school teaches has anything to do with me, or what we do here. My teachers don't understand 'cause they're not from here. Why should I care about what they're trying to teach me? I just need to graduate."

The Kukahiko (2017B) study on the transition and retention of Pacific Islander student-athletes, found that "unintentional" forms of cultural bias were more often responsible for experiences of cultural dissonance in education than "intentional" racism. The Kukahiko (2017B) study also suggests that cultural dissonance can negatively impact sense of belonging, internalization of collective responsibility, ability to recognize self-excellence, to love and be loved, total well-being, and willingness to see the world through alternative, multiple and simultaneous perspectives. The normalization of cultural racism forces Indigenous students to choose between home and school ontological frameworks, which create identity conflicts and cultural dissonance. Conversely, a significant amount of research suggests that strength, place and culture-based $\mathrm{P} 4$ that incorporates experiential learning strategies improve transition and retention for both students and teachers, while creating conditions for learning that improve literacy (Hejazi, Shahraray, M., Farsinejad, \& Asgary, 2009; Willms, 2003), increase sources of knowledge production, increase academic performance and better prepare students for employment, responsible citizenship, and fulfilling lives (Chetty, Friedman, Hilger, Saez, Schanzenbach \& Yagan, 2011). The approach is grounded in research around what works in strength, place and culturebased experiential learning associated with increased retention of content (Dochy, Segers, van den Bossche, \& Gijbels, 2003), enhanced problem-solving (Hung, et al., 2008), higher-order thinking skills (Shepherd, 1998), increased self-direction and lifelong learning (Chrispeels \& Martin, 1998).

\section{Problematizing the Achievement Gap}

The history of US colonization provides specific context to issues that surround the achievement gap between Native Hawaiian and Pacific Islanders (NHPI) students and non-NHPI students in Hawai 'i $i{ }^{16}$ The Office of Hawaiian Education (OHE) investigated various student outcome indicators that contributed to the "achievement gap" in HIDOE between 2015 and $2019 .{ }^{17}$ For the 2018-19 school year, OHE found that $34.7 \%$ of NHPI students tested at a level of "proficiency" (met standard or exceeded standard) in Language Arts, as compared to $63.1 \%$ of their non-PI peers $(28.4 \%$ achievement gap). During the same time period, $25 \%$ of NHPI students in the HIDOE tested at a level of proficiency in Mathematics, as compared to $51.4 \%$ of their non-PI peers 
(26.4\% Achievement gap). OHE challenged the claim that economic advantage was the leading indicator of academic proficiency by conducting a descriptive analysis of the socioeconomic (SES) variables in NHPI and non-NHPI student data. Low-SES and High-SES students were determined by students who qualified for "free lunch," and those who did not. ${ }^{18}$ By subtracting the proficiency rate ${ }^{19}$ of Low-SES NHPI students from High-SES NHPI students, OHE was able to isolate and calculate economic advantage $(E A)$ in proficiency raters, while minimizing cultural differences. Conversely, by subtracting the proficiency rate of High-SES NHPI students from High-SES nonNHPI students, OHE was able to isolate and calculate the impact of Cultural Dissonance (CD) and minimize EA. Thus, Total Advantage (TA) is the sum of EA and $\mathrm{CD}$, or the proficiency rate of Low-SES NHPI students subtracted from High-SES nonNHPI students. This became the OHE Cultural Dissonance Formula. This formula provides quantitative evidence that the achievement gap cannot be attributed to economic advantage alone, and corollary data suggests that cultural dissonance often has greater influence as a predictive indicator (see Tables 1 and 2 below). When corroborated with specific historical context, OHE's formula can be applied to various types of student outcome data to offer non-deficit and non-Eugenic-based analyses.

\section{Table 1}

\section{8-19 HIDOE Language Arts Proficiency by Gender \& Culture}

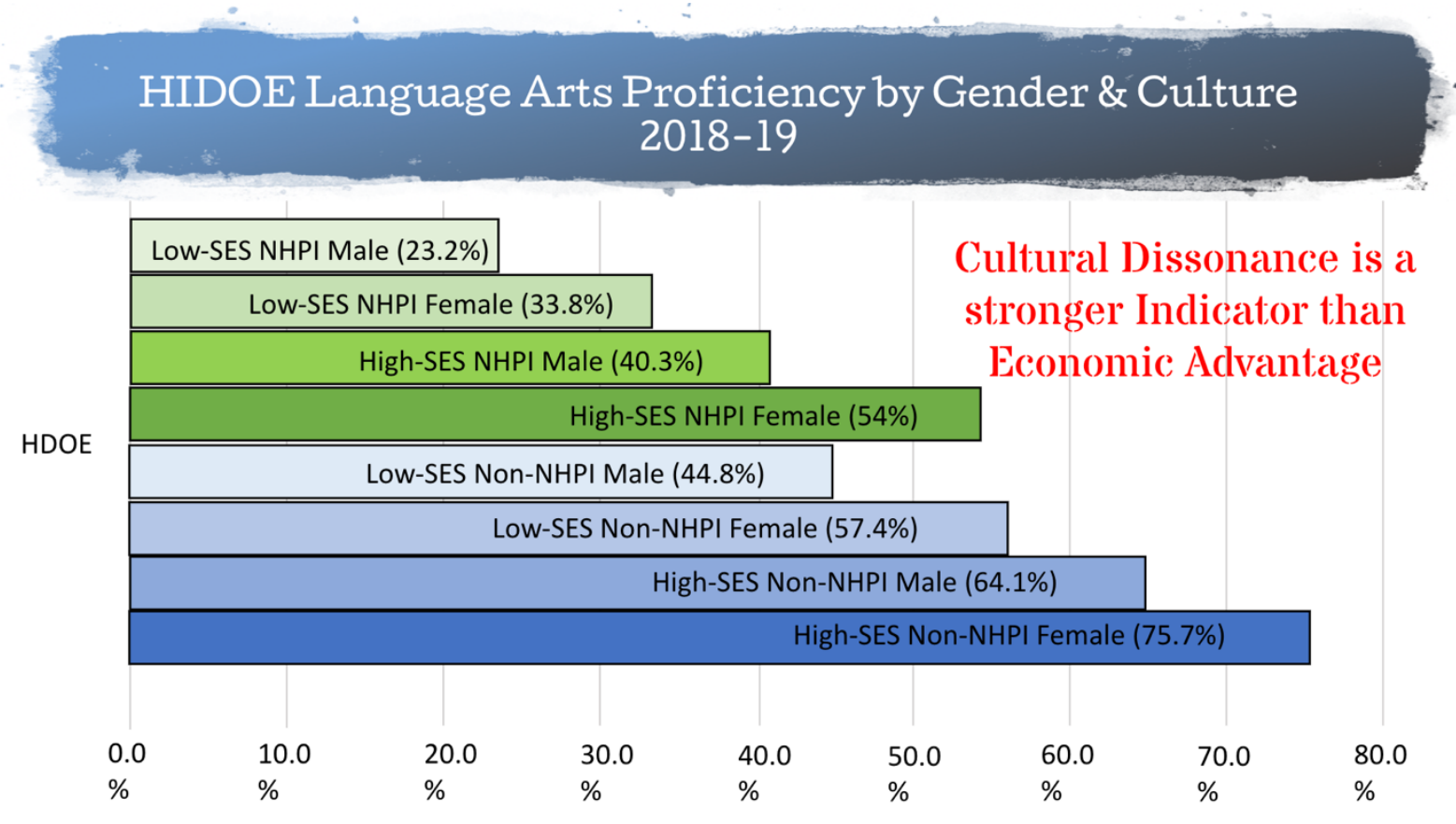


Table 2

2018-19 HIDOE Math Proficiency by Gender \& Culture

\section{HIDOE Math Proficiency by Gender \& Culture 2018-19}

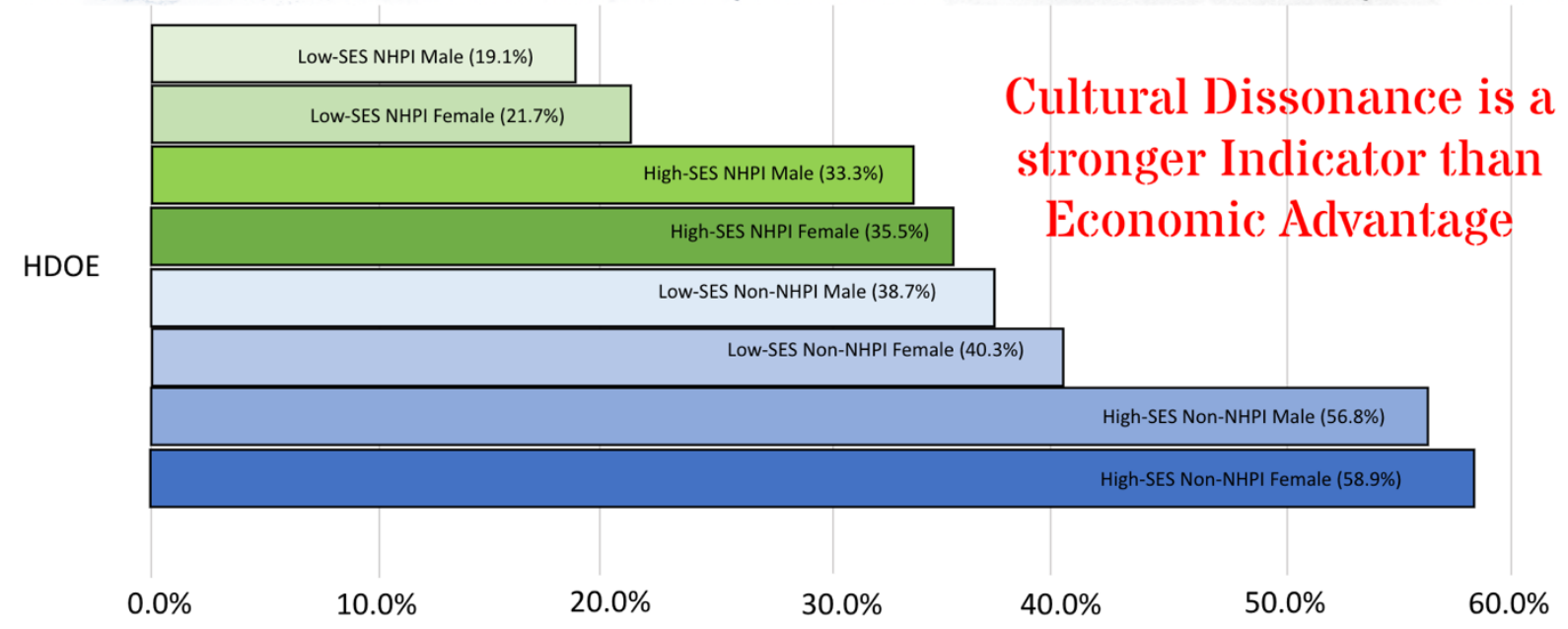

\section{School to Prison Pipeline}

Umemoto, Spencer, Miao, and Momen (2012) conducted a ten-year study of the juvenile justice system in Hawai $i$, and found that NHPI youth accounted for 77,457 juvenile arrests (49.4\%), or nearly half of the total juvenile arrests in Hawai'i between 2000 and 2010. NHPI youth were the only group to increase their percentage at each stage of the criminal system and were arrested 2.53 times as often as White, Japanese, Korean and Chinese youth combined (77,457 vs. 30,585$)$, and incarcerated at 2.06 times the rate of all Non-NHPI groups combined (Umemoto et al, 2012). Krezmien, Leone \& Wilson, (2014) research on school to prison pipelines predicts that racial and ethnic groups that are over-represented in juvenile arrest data, will also be over-represented in school discipline categories and adult incarceration. The Office of Hawaiian Affairs report (OHA, 2010) also found that the percentage of adult $\mathrm{NH}$ representation increases as they progress through the criminal system, while the percentage of other non-NHPI groups are decreasing. Between 2015 and 2019, only three racial groups of K-12 students in the HIDOE maintained suspension rates over $50 \%$ for the four consecutive school years: Samoan, Micronesian, and Native Hawaiian. ${ }^{20}$ The analysis of the disciplinary data, however, found that the suspension rates masked the inequitable rate of "contact" (represented by the number of incident reports) between NHPI and non-NHPI students, which lead to an over-representation in total out of school suspensions. ${ }^{21}$ Despite representing only $35 \%$ of the total HIDOE 
student population from 2015 to 2019 , NHPI students represented $58.7 \%$ of the total suspensions and $59.6 \%$ of total incident reports. The OHE (2020) report found that $\mathrm{NH}$ students represented $44 \%$ of total suspensions, $45 \%$ of total incident reports, $42.86 \%$ total violent incidents, and $38.43 \%$ of total dismissals. ${ }^{22}$ This data mirrored the $\mathrm{NH}$ representation in the juvenile justice system ( $41.6 \%$ of total juvenile arrests) AND the $\mathrm{NH}$ representation of total incarcerated adults in Hawai' $i$ (39\%), which suggests an active school to prison pipeline. ${ }^{23}$

Mother of a Native Hawaiian junior high school student in HIDOE: "Last year my son was identified for Special Education, which I was told would provide him more resources. This year I got a call from the vice principal telling me they were going to suspend [my son], but I asked how could they do that to special needs kids without an IEP meeting, and why they don't have more resources to deal with his actions other than suspending him. These teachers are not from here, and they think they are going to change these boys without understanding our culture, or where we are from. They are trying to change the kids to be more like them, but we were taught if people do not respect you, then [expletive]'em. These teachers have no idea what to do with [my son], or how to connect to him. They see our Hawaiian boys as problems they need to discipline."

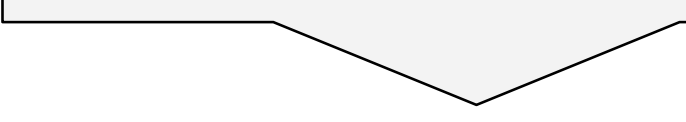

\section{Student-Teacher Congruency}

The data analyses also discovered that the four student populations with the lowest representation in the disciplinary data, were also the only racial groups with teacher representation percentages greater than or equal to their student representation percentages (see Table 3). Chinese teacher representation was $106.67 \%$ of its student population, Japanese teacher representation was $257.14 \%$ of its student population, Korean teacher representation was $109.09 \%$ of its student population, and White teacher representation was $134.95 \%$ of its student population. Research suggests that physical representation (or "visibility") of students' race, ethnicity, culture and gender in the student body, staff, faculty, and administration are associated with improved academic achievement (Dee, 2004; Egalite \& Kisida, 2018; Gershenson, Hart, Hyman, Lindsay, \& Papageorge, 2018), and symbolize "attainable" and "realistic" professional aspirations. Conversely, "invisibility" in educational environments can negatively impact sense of belonging, transition, persistence, degree attainment and college participation (Kukahiko, 2015; Kukahiko, 2017A; Teranishi, 2009; Uperesa, 2015; Wright, 2003). In short, student populations that maintained at least a 1:1 congruence with the teacher population achieved the highest academic proficiency rates, and the lowest 
representation in all disciplinary categories. This analysis does not assume that cultural dissonance is activated by individual teachers as intentional forms of racism, but that unconscious bias (Gershenson \& Dee, 2017; Grissom \& Redding, 2015; Holt \& Papageorge, 2016) and apathy produce the same negative outcomes as intentional racism and discrimination.

Table 3

Teacher Congruency to Student Population (2018-19)

\begin{tabular}{|c|c|c|c|c|}
\hline Cultural Identity & \# Teachers & $\begin{array}{c}\% \text { of Teacher } \\
\text { Population }\end{array}$ & $\begin{array}{c}\% \text { of Student } \\
\text { Population }\end{array}$ & $\begin{array}{c}\% \text { to } \\
\text { Congruency }\end{array}$ \\
\hline Japanese & 2686 & $23.40 \%$ & $9.10 \%$ & $\mathbf{2 5 7 . 1 4 \%}$ \\
\hline White & 2881 & $25.10 \%$ & $18.60 \%$ & $\mathbf{1 3 4 . 9 5 \%}$ \\
\hline Korean & 139 & $1.20 \%$ & $1.10 \%$ & $\mathbf{1 0 9 . 0 9 \%}$ \\
\hline Chinese & 367 & $3.20 \%$ & $3.00 \%$ & $\mathbf{1 0 6 . 6 7 \%}$ \\
\hline Hawaiian & 1209 & $10.50 \%$ & $24.80 \%$ & $42.34 \%$ \\
\hline Black & 105 & $0.90 \%$ & $2.80 \%$ & $32.14 \%$ \\
\hline Filipino & 804 & $7 \%$ & $22.40 \%$ & $31.25 \%$ \\
\hline Samoan & 64 & $0.50 \%$ & $3.30 \%$ & $15.15 \%$ \\
\hline
\end{tabular}

To improve the conditions of a'o between teachers and students, OHE has since designed and implemented professional development (PD) programs that connect HIDOE stakeholders to traditional sources of knowledge production through culturally relevant P4 (practices, projects, programs and policies), which can also embed standard core curriculum as secondary content knowledge within Hawaiian cultural ways of

A'o: teaching and learning as a sustainable practice where students/apprentice s master their craft and internalize their role in the community and responsibility to pass that knowledge on to the next generation. knowing. OHE's PD services remain available to all schools in HIDOE that request them, but cannot be mandated, and therefore, limits the institutionalization of strength, place and culture-based education. In 2007, a collaboration between Kamehameha Schools and HIDOE piloted a version of this PD as part of a teacher induction program called the Kahua Program, but the program was discontinued due to the perceived high-cost of maintenance. A study that came out five years later (Thigpen, 2012), however, found that the teacher inductee participants of the Kahua program were better prepared to reduce cultural dissonance associated 
with the incongruency of student-teacher populations. It is the perspective of OHE, however, that the application of this PD should not be limited to new teachers within induction programs, but also available to in-service teachers. This in-service teacher population includes individuals who may have grown up in Hawai' $\mathrm{i}$, but may have been conditioned by compulsory education to play host to the system (Bowles \& Gintis, 1976; Fine, 1991; Freire, 1973; Willis \& Willis, 1981) and replicate a model of US continental education that reproduces cultural racism and cultural dissonance.

\section{College Aspiration-Participation Gap}

Although $78 \%$ of all $\mathrm{NH}$ students in the HIDOE had college aspirations of attaining at least a 2-year degree in 2017 (ACT, 2017), only 45\% ended up enrolling at US institutions of higher education in 2018 (HIDOE, 2020A). This statistic suggests that obstacles, or perceived barriers, are impeding the matriculation of $\mathrm{NH}$ high school students who want to go to college, but do not. Large gaps between college aspiration and educational attainment for $\mathrm{NH}$ students are especially concerning, because high school drop out rates become entrenched (systemic) when students perceive college aspirations as unrealistic (Roderick, 2006). In 2018, the HIDOE senior cohort had a $12.2 \%$ dropout rate (HIDOE, 2018), while the $\mathrm{NH}$ student population within that same cohort experienced a $19 \%$ dropout rate, which represented $567 \mathrm{NH}$ students that did not complete their high school degree, and $40 \%$ of HIDOE's total high school dropouts from the 2018 senior cohort. Considering $75 \%$ of all American state prisoners and 59\% of all federal prisoners did not complete high school (Harlow, 2003), mitigating cultural dissonance is the most important task in deconstructing the school to prison pipeline.

\section{Michael Robinson Vice President, Government Relations \& Community Affairs} in Testimony in Support of HB $\mathbf{3 3 0}$ Relating to Suicide Prevention: "A teen in Hawaii is nearly twice as likely to attempt suicide as a teen elsewhere in the United States, with 2,280 reporting having attempted suicide here in 2007, according to a Centers for Disease Control survey in Hawaii's schools. This data has been confirmed by the Department of Health which found that Hawaii has the highest attempted suicide rate in the country for youth ages 10 to 24 . For every suicide death in the islands, there are 25 attempted suicides. The neighbor islands have a higher suicide attempt rate among the youth than Oahu. While suicide or suicide attempt is troubling at any age, youth suicide has unique challenges." 


\section{Suicide Amongst NHPI Adolescents}

Suicide is a symptom of what Alfred (2009) calls anomie, which is defined as "the state of profound alienation that results from experiencing serious cultural dissolution, which is then the direct cause of serious substance abuse problems, suicide and interpersonal violence" (p. 49). Trask (1999) also addresses the psychophysical effects of cultural dissonance as the "psychological injuries suffered by the colonized that continue to wound our internal and external lives" (pp. 102-103). This article does not attempt to generalize the cause of individual experiences with depression and suicide, but simply call attention to the large amounts of research that affirm a highly correlated relationship between cultural dissonance and suicide amongst NHPI adolescents (Ta, Chao \& Kaholokula, 2010; Wong, Sugimoto-Matsuda, Chang \& Hishinuma, 2012; Yuen, Hishinuma \& Miyamoto, 2000). NHPI adolescents are at the highest risk of suicide in the United States, and Wong et al. (2012) suggests this is highly correlated to "acculturative stress and cultural conflict" (p. 169).$^{24}$ In another study of suicide amongst $\mathrm{NH}$ high school adolescents (Yuen et al., 2000), NH adolescents were 33\% more likely to attempt suicide than Non-Native Hawaiians. Students whose main wage earners had a high school education or less, were twice as likely (21.9\%) to attempt suicide than those with main wage earners who had some college education (10.7\%), while there was no such correlation for non-Native Hawaiians. Cultural dissonance was a higher predictor for suicide attempts by $\mathrm{NH}$ adolescents, independent of ethnicity, SES and psychopathology. ${ }^{25}$ While NH females had attempted suicide more frequently than males, Hawaiian males in $9^{\text {th }}$ and $12^{\text {th }}$ grade were 2.39 times more likely to attempt suicide as compared to Non-Hawaiian adolescents, suggesting transition points are especially problematic for this population. The identification of culturally responsive educational P4 that disrupts cultural dissonance by setting learning conditions that improve self-worth, sense of belonging, connections to others, etc., also becomes important to the work of reducing suicide amongst NHPI adolescents.

\section{Tenet 3: Constellating Critical Praxis and Interest Convergence}

The constellation of critical praxis ${ }^{26}$ (Freire, 1970) is a process to inform action, challenge legal neutrality ${ }^{27}$ (Ladson-Billings, 1995), and enact transformative change. OHE defines critical praxis as informed action for systemic change that is operationalized through culturally responsive educational P4. The fusing of critical praxis with interest convergence ${ }^{28}$ (Bell, 1979) can polarize stakeholders around values that they already believe in, and make it uncomfortable for them to stay in neutral spaces. When these values become institutionalized, the resulting policies become opportunities for interest convergence and further normalization through the implementation of culturally responsive educational P4 (practices, projects, programs and policies). OHE recognized that the goals and desired student outcomes for 
strength, place and culture-based education did not come at the cost of desired academic student outcomes. Conversely, a significant amount of research suggests that strength, place and culture-based P4 that incorporates experiential learning strategies improve transition and retention for both students and teachers, while creating conditions for learning that improve literacy (Hejazi, Shahraray, M., Farsinejad, \& Asgary, 2009; Willms, 2003), increase sources of knowledge production, increase academic performance and better prepare students for employment, responsible citizenship, and fulfilling lives (Chetty, Friedman, Hilger, Saez, Schanzenbach, \& Yagan, 2011). The approach is grounded in research around what works in strength, place and culture-based experiential learning associated with increased retention of content (Dochy, Segers, van den Bossche, \& Gijbels, 2003), enhanced problem-solving (Hung, et al., 2008), higher-order thinking skills (Shepherd, 1998), increased self-direction and lifelong learning (Chrispeels \& Martin, 1998).

\section{Current Examples of Interest Convergence Opportunities for Hawaiian Education}

The Office of Hawaiian Affairs was created in 1978, which created political leverage to amend the state constitution to include Article X (Section 4) and Article XV (Section 4). The first is a policy that mandated the State of Hawai' $i$ to promote "the study of Hawaiian culture, history and language" by providing a Hawaiian education program and using community expertise "as a suitable and essential means in furtherance of Hawaiian education." The interest convergence provided by Article X (Section 4) enabled the realization of two educational P4 in 1980 that still exist today: the Hawaiian Studies Program and the Kupuna Component. Article XV (Section 4), officially recognized Hawaiian as an official language of the State, which later provided the interest convergence for the Hawaiian Language Immersion Program of 1986 (HIDOE, 2020A). Most recently, the creation of OHE and E-3 Policy (Nā Hopena A'o HA Framework) in 2015, and the HIDOE Strategic Plan 2020-2030 (HIDOE, 2020B), or HIDOE Promis Plan, have continued to set the conditions that challenge the model of compulsory education that has existed in Hawai'i for over 120 years. COVID-19, however, represents the most recent opportunity for interest convergence in shifting compulsory education into a sustainable model of a'o that might realize a healthier, more equitable, empathetic, innovative and sustainable Hawai'i beyond the COVID pandemic. 


\section{Tenet 4: Reconnect Stakeholders to Traditional Sources of Knowledge Production}

\section{Design Educational P4 Through Cultural Survivance}

Within the context of Hawaiian education, stakeholders and constituents have illustrated a committed political interest in reclamation of the Hawaiian language, history, communal definitions of success, and ways of knowing as a matter of cultural survivance. Vizenor (2008) defines cultural survivance as the "active survival and resistance to cultural dominance” (p. 24). Goodyear-Ka‘ōpua's (2013) work in Hawaiian education focuses on the sustainable quality of cultural survivance, as a "renewal and continuity into the future rather than loss and mere survival through welcoming unpredictable cultural reorientations" (p. xii). Within the context of Hawaiian education, cultural survivance is an important component to a sustainable educational futurity, and will require Hawaiian knowledge production to become relevant and normalized outside of the classroom, and beyond high school graduation. This approach to the design of educational P4 (practices, projects, programs and policies) reconnects stakeholders to traditional sources of Hawaiian knowledge production, and provides them strength, place and culture-based responses to contemporary circumstances that cause cultural dissonance.

The Kohala Center is just one community educational organization that provides strength, place and culture-based education as cultural survivance to K12 students on the island of Hawai' $\mathrm{i}$. The organization accesses the spiritual and the sacred through ritual, a prerequisite for effectively advancing the science of sustainability, the management of natural resources, and the conservation of nature. When educators use spiritual approaches rooted in the cultural practices of Hawai' $i$ it provides students and teachers "a powerful portal to revealing, supporting, and enhancing our collective aloha (love, fondness, reciprocity, as with a family member) for and dedication to the places and processes that we steward" (Kealiikanakaoleohaililani, Kurashima,

huli: taro shoot for planting

kalo: taro

lo'i: irrigated terrace especially for tarop

aloha: love, fondness, reciprocity, as with a family member

kumu: teacher

'āina: land

mahi'ai: farmer

nā pilina: symbiotic or equitable connections/relationships ahupua'a: Landscape segments from the ocean to the mountain that served as the traditional human support systems.

wai: water

ma uka: upland

ma kai: seawardsp 
Francisco, Giardina, Louis, McMillen, \& Camara, 2018). Ka'iana Runnels is a kumu for the program, and manifests genealogical relationships between students and the 'āina through cultural practices and protocols of a mahi'ai. Ka'iana introduces students to land management techniques and strategies that help them to understand nā pilina between: (1) the organisms that live within the ahupua'a, (2) the students land management work and the sustainability of the ecosystem, (3) each other in the mastery of skills, and (4) the students' work and the larger community.

Ka'iana adeptly embeds language, history, math, and science into the cultural practices of land management as secondary content knowledge. Often the application of these secondary content skills happen within unfamiliar contexts, and requires students to collaborate and find creative applications of learned knowledge to solve for unforeseen conditions. For example, Ka'iana asks students, "What is sustainability, and what does it look like? What are the consequences of moving away from the ahupua'a system, and what are symptoms we see today? Why must we always return wai to its source? Wai naturally moves vertically from ma uka to ma kai, but what are the consequences of moving wai horizontally across the 'âina, like the sugar cane flumes of the plantations, or even across multiple ahupua'a? What happens to the land below these horizontal pipelines, and what is the impact on the 'āina you can see today? If each huli have to be spaced so far apart, what is the rate and capacity of kalo growth for the lo'i, how many people can we feed, and for how long? Ka'iana and the Kohala Center illustrate how education can reconnect students to traditional sources of Hawaiian knowledge production that inherently provides food security, but more importantly, make them better stewards of these lands, contributing members of their families and communities, and more fulfilled individuals who have a deeper sense of who they are (See Kohala center program video: https://kohalacenter.org/farmer training/ohaha).

\section{Conclusion}

During an Educator of the Year panel for the Native Hawaiian Education Association in July of 2020, the director of OHE Kau'i Sang was asked "What would be your call to action in moving Hawaiian education forward?" Her simple answer was "to remember." Remember the mo'olelo of our kūpuna, which details thousands of years of "best practices," so that we know how to holomua (move forward). Remember what we have sacrificed and overcome during the Hawaiian education movement, so that we might be made pa'a (firm) in our commitment to continue moving it forward. Lastly, she said to remember the opportunities for change that each of us have gained through the events that have altered our current landscapes (i.e., COVID pandemic and BLM), and to realize those opportunities and actualize them through our critical praxis. An investigation into the historical context of Hawaiian education has provided HIDOE 
stakeholders with a point of origin for "best practices," and informs educational initiatives and P4 on how to recalibrate contemporary circumstances for "drift." The desired futurity for Hawaiian education is one that exists within a sustainable model of a'o through strength, place and culture-based pedagogies. Continued research using the OHE Theory of Change can ensure that contemporary circumstances are met within an informed and preemptive process that continues to shift educational stakeholder goals and outcomes towards this desired futurity.

\section{Notes}

1. Contemporary examples of foreign encroachment include Mauna o Wākea, continued military occupation, and the real estate market where exorbitant prices are driven by foreign investors and wealthy retirees from abroad.

2. The authors understand that the definitions of ontology, axiology, methodology and epistemology do not perfectly align within their etymology, and want to be transparent about using these definitions as a way to develop a common vocabulary that stakeholders can reference when discussing shifts in traditional Hawaiian knowledge production.

3. OHE uses the HĀ Campus Climate Survey as a longitudinal tool to measure the improvement of BREATH amongst all HIDOE stakeholders: Belonging, Responsibility, Excellence, Aloha, Total Well-Being and Hawai'i.

4. Dr. Kalehua Krug (2014) establishes the use of mo'olelo to research the originanl intentions and practices of Hawaiian education.

5. This history was originally written by Samuel Manaiakalani Kamakau in Hawaiian as a series of newspaper articles in the Ka Hoku o Hawai' $i$ during the 1860s and 1870s. 6 . This constant comparative analysis was conducted on both the original mo'olelo written in the Hawaiian language, as well as the English translated version that came after.

7. The triangulation of 'olelo no'eau was a validation process used to check whether the researcher observations were aligned with a Hawaiian ontological framework, a research method often used by Native and Indigenous scholars (Kahakalau, 2019). This method also provided guidelines for consistency to clearly identify the nuances within the mo'olelo during the coding process.

8. Joseph Moku'ōhai Poepoe was a writer, translator, editor, attorney and politician who is also an important historian by practice, due to the importance of the books he wrote and contributions he made in preserving cultural knowledge within the Hawaiian newspapers.

9. Perreira's (2013) literary analysis of mo'olelo seeks to identify the iwi hilo (the very core of one's being) within the 'ōlelo Hawai' $i$, finding the most essential of qualities 
amongst its finite pieces and metaphorical allusions: the literal intent and cultural context.

10. OHE currently provides professional development that allow teachers the opportunity to experience strength, place and culture-based education, so that they are equipped to frame learning within the appropriate intentionality and context. 11. The Kapu System was the religious and political framework which governed the Hawaiian islands. When the Kapu System fell in 1819, space was made for foreign influence to take hold (Osorio, 2002).

12. The Hawaiian Constitution of 1840 was drafted by William Richards, Gerrit Judd and Richard Armstrong; white missionary businessmen who used their roles as moral and spiritual guides to legislate capitalism as important Christian values. These laws drove a deeper separation between commoners and the ali $i$, and for the first time made a distinction between the King's land and government land.

13. The Mahele is made up of five separate events between 1845 and 1855, which privatized land ownership and include the Residency Laws and Kuleana Act of 1850. 14. The 1960 Act to regulate names was followed by the 1863 Law of Naming, which forced Hawaiian children to 1) take their father's name as the last name, or family name, 2) a Hawaiian middle name, and 3) an English or biblical first name, or given name. This naming methodology disrupted the balance between matrilineal and patriarchal lineages, and set the stage for colonial dispossession through male inheritance and erasure of Hawaiian identity via blood-quantum logic.

15. For a detailed timeline of events Osorio (2002) and Merry (2000) narrate the severing of Native Hawaiians from their cultural, intellectual and political sovereignty. Additional examples include the Overthrow of the Hawaiian Monarchy in 1893, the Illegal Annexation of Hawai'i by the United States in 1896, the English Only Law of 1896, and the Hawaiian Homes Commission Act (HCCA) of 1920 that defined Hawaiians by $50 \%$ blood quantum.

16. The NHPI classification includes Native Hawaiians, Samoans, Tongan, Guamanians, Micronesian, and other Pacific Islanders, while Non-PI students include all other student groups within the HIDOE Longitudinal Data System (LDS). 17. Howard (2015) defines the achievement gap as "the discrepancy in educational outcomes between various student groups" (p. 11), and insists that comparisons "must be informed by both a historical understanding of the experiences of those groups in the United States, and an examination of the correlation between their systemic exclusion from educational opportunities and the current state of their educational performance" (p. 12).

18. Socioeconomic status (SES) is indicated within HIDOE Longitudinal Data System (LDS) by those students that qualify for "free-lunch." This is determined by household income and need when students register for school. 
19. Percentage of students who "Met" or "Exceeded" proficiency standards in Smarter Balanced Assessments (SBA) Language Arts and Math.

20. Tongan students sustained suspension rates over $50 \%$ for three of the four school years, and maintained the fourth highest suspension rate.

21. When OHE applied the Cultural Dissonance Formula to the suspension rates for $\mathrm{NH}$ students from 2015 to 2019, economic advantage (1.9-5.4\%) and cultural dissonance (.3\% to $9.8 \%)$ was very low. This was an expected outcome due to the use of Chapter 19 , a statewide document in Hawai' $i$ that prescribes disciplinary actions based on the "offense," regardless of SES or cultural identity.

22. $86.75 \%$ of $\mathrm{NH}$ dismissals were $\mathrm{NH}$ males (OHE, 2020).

23. When $\mathrm{OHE}$ calculated the over-representation of $\mathrm{NH}$ students in the identification and suspension process in HIDOE from 2015-2019, NH students were overrepresented in incident reports (187-191\%) and out of school suspensions (170-185\%). $\mathrm{NH}$ Special Education students were over-represented in incident reports (347-363\%) and out of school suspensions (353-373\%). NH male special education students were over-represented in incident reports (435-448\%) and out of school suspensions (426$456 \%)$.

24. The findings also support the work of Ta et al. (2010), whose study of depression in $\mathrm{NH}$ women found evidence that linked depression to acculturation, US occupation and their social status as Native people.

25. Yuen et al. (2000) used the Hawaiian Culture Scale-Adolescent Version in their data collection and analysis, which can be used to measure cultural dissonance by setting dominant colonial culture as the "norm," or default, and calculating the distance between zero (the "norm") and NH students' cultural affinity to Hawaiian beliefs, cultural practices, language, etc.

26. Critical praxis is the combination of knowledge and action, the inherent outcome of critical consciousness development (Freire, 1970).

27. Neutrality is the belief that doing nothing, despite the recognition of social injustice, is a neutral act, rather than a deliberate decision to maintain the status quo. Gloria Ladson-Billings (1995) suggests that neutrality is racism, and challenges traditional claims of legal neutrality, objectivity, and color-blindness (whiteness, individualism and meritocracy) in education as camouflages for the self-interest of dominant groups in American society.

28. Bell (1979) suggested that dominant groups do not negotiate changes in status quo with non-dominant groups unless their interests converge. Bell (1979) explains how International diplomatic agendas during the Civil Rights movement were negatively impacted by the critique of social justice issues in the US, and international pressure created interest convergence for the educational policies introduced by Brown vs. Board of Education. 


\section{References}

ACT (2017). The Condition of College \& Career Readiness 2017: Hawaii Key Findings.

Alcantara, L., Keahiolalo, R., \& Pierce, S. (2016). World-class Hawaiian culture-based education: Exploring foundational understandings. Honolulu, HI: Ho 'olaukoa Educational Systems \& Strategies, Kamehameha Schools.

Alfred, G. R. (2009). Peace, power, righteousness: An indigenous manifesto. Oxford University Press, USA.

Allen, W. R. (Ed.) (1991). College in Black and White: African-American Students in Predominantly White and Historically Black Colleges and Universities Frontiers in Education. Albany, NY: State University of New York Press.

Battiste, M. (2002). Indigenous knowledge and pedagogy in First Nations education: A literature review with recommendations (pp. 1-69). Ottawa: National Working Group on Education.

Bell Jr, D. A. (1979). Brown v. Board of Education and the interest-convergence dilemma. Harv. L. Rev., 93, 518.

Bowen, G. A. (2009). Document analysis as a qualitative research method. Qualitative Research Journal, 9(2), 27-40. doi:10.3316/QRJ0902027

Bowles, S., \& Gintis, H. (1976). 1976 Schooling in Capitalist America. New York: Basic.

Castagno, A. E., \& Brayboy, B. M. J. (2008). Culturally responsive schooling for Indigenous youth: A review of the literature. Review of Educational Research, 78(4), 941-993.

Charlot, J. (2005). Classical Hawaiian Education. Retrieved from http://www.john charlot.me/BOOKS/CHE\%20post/che.pdf

Chun, M. N. (2011). No nā mamo: Traditional and contemporary Hawaiian beliefs and practices. Honolulu: University of Hawai'i Press.

Consedine, R., \& Consedine, J. (2005). Healing our history: The challenge of The Treaty of Waitangi (updated ed.). Auckland: Penguin Books.

Creswell, J. W. (2003). Research design: Qualitative, quantitative, and mixed methods approaches (2nd ed.). Thousand Oaks, CA: Sage.

Creswell, J. W., \& Plano Clark, V. L. (2011). Choosing a mixed methods design. Designing and conducting mixed methods research, 2, 53-106.

Clark, V. L. P., \& Creswell, J. W. (2008). The mixed methods reader. Sage.

Demmert Jr, W. G., \& Towner, J. C. (2003). A Review of the Research Literature on the Influences of Culturally Based Education on the Academic Performance of Native American Students. Final Paper.

Diaz, V. M. (2004). To 'P' or Not to 'P': Marking the Territory Between Pacific Islander and Asian American Studies. Journal of Asian American Studies, 7(3), 183-208.

Diaz, V., \& Kauanui, J. K. (2001). Native Pacific cultural studies on the edge. Contemporary Pacific, 13(2), 315-341. 
Dockery, A. M. (2009, October). Cultural dimensions of Indigenous participation in education and training. In Australian Conference of Economists (ACE09) Paper.

EPIC (2014). Native Hawaiian Pacific Islanders: A community of contrasts in the United States 2014. Los Angeles: Author.

Evenhuis, N. L., \& Fitzsimmons, J. M. (Eds.). (2007). Biology of Hawaiian Streams and Estuaries: Proceedings of the Symposium on the Biology of Hawaiian Streams and Estuaries: Hilo, Hawai'i, 26-27 April 2005 (Vol. 3). Bishop Museum Press.

Fine, M. (1991). Framing dropouts: Notes on the politics of an urban high school. Suny Press.

Fleischman, R., Tyson, T. N. (2000). The interface of race and accounting: The case of Hawaiian sugar plantations, 1835-1920. Accounting History, 5 (1). Retrieved from https://doi.org/10.1177/103237320000500102

Freire, P. (1970). Pedagogy of the Oppressed. First Published in USA by Herder and Herder.

Freire, P. (1973). Education for critical consciousness (Vol. 1). Bloomsbury Publishing.

Goodyear-Ka 'ōpua, N., \& Kuwada, B. K. (2018). Making 'Aha: Independent Hawaiian Pasts, Presents \& Futures. Daedalus, 147(2), 49-59.

Goodyear-Ka'ōpua, N. (2013). The seeds we planted: Portraits of a native Hawaiian charter school. University of Minnesota Press.

Gyory, A. (1998). Closing the gate: Race, politics, and the Chinese Exclusion Act. University of North Carolina Press.

Hale, C. (2008). Engaging Contradictions: Theory, Politics, and Methods of Activist Scholarship. Berkeley: University of California Press.

Hall, L. K. (2015). Which of these things is not like the other: Hawaiians and other Pacific Islanders are not Asian Americans, and all Pacific Islanders are not Hawaiian. American Quarterly, 67(3), 727-747.

Harlow, C. W. (2003). Education and correctional populations. Washington, DC: US Department of Justice, Office of Justice Programs.

HIDOE (2015A). Plan for Office of Hawaiian Education Priorities: 3-year strategic plan. Retrieved from http://www.hawaiipublicschools.org/DOE\%20Forms/Hawaiian/ OHE_DeliveryPlan.pdf

HIDOE (2015B). Department advances Hawaiian Education. Retrieved from http://www. hawaiipublicschools.org/ConnectWithUs/MediaRoom/PressReleases/Pages/Hawaii an-Ed.aspx

HIDOE (2018). 2018 Hawaii Department of Education Data Book. Retrieved from http:// arch.k12.hi.us/PDFs/state/databook/2018/2018HIDOEDatabook.pdf

HIDOE (2020A). History of Hawaiian Education. Retrieved from http://www.hawaiipublic schools.org/TeachingAndLearning/StudentLearning/HawaiianEducation/Pages/Hist ory-of-the-Hawaiian-Education-program.aspx

HIDOE (2020B). 2030 Promise Plan. Retrieved from http://www.hawaiipublicschools. org/DOE\%20Forms/Advancing\%20Education/2030PromisePlan.pdf 
Jayakumar, U. M., \& Museus, S. D. (2012). Mapping the intersection of campus cultures and equitable outcomes among racially diverse student populations. In Creating Campus Cultures (pp. 11-37). Routledge.

Kahakalau, K. (2019). Treading on the trail of honor and responsibility. The past before us: Mo'okü'auhau as methodology, 9.

Kauanui, J. K. (2008). Hawaiian blood: Colonialism and the politics of sovereignty and indigeneity. Durham: Duke University Press.

Kana'iaupuni, S. (2007). A brief overview of culture-based education. Honolulu: Kamehameha Schools Research \& Evaluation Division.

Kawakami, A.J., \& Aton, K.K. (2001). Ke a'o Hawaii (critical elements of Hawaiian learning): Perceptions of successful Hawaiian educators. Pacific Educational Research Journal, 11(1), 53-66.

Kawano, L. (2020, April 17). Unemployment in Hawaii tops $37 \%$ as coronavirus shutdown continues. Retrieved from https://www.hawaiinewsnow.com/2020/04/16/ unemployment-hawaii-tops-coronavirus-shutdown-continues/

Kealiikanakaoleohaililani, K., Kurashima, N., Francisco, K. S., Giardina, C. P., Louis, R. P., McMillen, H., ... \& Camara, K. (2018). Ritual+ sustainability science? A portal into the science of aloha. Sustainability, 10(10), 3478.

Krezmien, M. P., Leone, P. E., \& Wilson, M. G. (2014). Marginalized students, school exclusion, and the school-to-prison pipeline. Juvenile justice sourcebook, 267.

Kukahiko, K.T. (2017A). Getting in: College choice for Pacific Islander high school football recruits. State society and governance in Melanesia discussion papers. Special Issue: Pacific Islanders in Sport. Canberra: Australian National University Press.

Kukahiko, K. T. (2017B). Staying in: The study of Pacific Islanders in college football using Indigenous methodologies. Asian Journal of Social Science Studies, 2(4), 19.

Kukahiko, K.T. (2015). Racial diversity deficit in college football: Fixing the pipeline. Journal of Critical Race Inquiry, 2(2), 25-53. Retrieved from http://ojs.library. queensu.ca/index.php/CRI/article/view/4631/5406

Ladson-Billings, G. (2006). From the achievement gap to the education debt: Understanding achievement in US schools. Educational researcher, 35(7), 3-12.

Lomawaima, K. T., \& McCarty, T. L. (2002). When tribal sovereignty challenges democracy: American Indian education and the democratic ideal. American Educational Research Journal, 39(2), 279-305. https://doi.org/10.3102/00028312 039002279

Lucas, P. F. N. (2000). E ola mau kakou i ka'olelo makuahine: Hawaiian language policy and the courts. Hawaiian Journal of History, 34. Retrieved from http://hdl.handle. net/10524/431

Morita, M. K. (2013). A study of Pacific Islander scholarship football players and their institutional experience in higher education. University of Southern California. 
Museus, S. D., \& Quaye, S. J. (2009). Toward an intercultural perspective of racial and ethnic minority college student persistence. The Review of Higher Education, 33(1), 67-94.

Nee-Benham, M. K., \& Heck, R. H. (1998). Culture and educational policy in Hawai'i: The silencing of Native voices. Psychology Press.

OHA (2010). The disparate treatment of native Hawaiians in the criminal justice system. Honolulu, Hi.: Office of Hawaiian Affairs.

OHA (2017). A Native Hawaiian Focus on the Hawai' $i$ Public School System, SY 2015: Ho'na'auao (Education) Fact Sheet, Vol. 2017, No. 1. Retrieved from https://19of 32x2yl33s8o4xza0gf14-wpengine.netdna-ssl.com/wp-content/uploads/A-NativeHawaiian-Focus-on-the-Hawaii-Public-School-System.pdf

OHE (2020). Office of Hawaiian Education (OHE) cultural dissonance formula: Demystifying the "achievement gap."

Osorio, J. K. (2002). Dismembering Lahui. Amsterdam, Netherlands: Amsterdam University Press.

Polansek, T., \& Huffstutter, P. J. (2020, April 27). Piglets aborted, chickens gassed as pandemic slams meat sector. Retrieved from https://apple.news/AVF942K1LTZi2P czNM8cW2w

Roderick, M. (2006). Closing the aspirations-attainment gap: Implications for high school reform. A commentary from Chicago. MDRC.

Rothwell, J., \& VanDrie, H. (2020, April 27). The effect of COVID-19 and disease suppression policies on labor markets: A preliminary analysis of the data. Retrieved from https://www.brookings.edu/research/the-effect-of-COVID-19-and-diseasesuppression-policies-on-labor-markets-a-preliminary-analysis-of-the-data/

Said, E. W. (2012). Culture and imperialism. Vintage.

Silva, N. K. (2004). Aloha betrayed: Native Hawaiian resistance to American colonialism. Duke University Press.

Smith, L. T. (1999). Decolonizing methodologies: Research and Indigenous peoples. Zed Books.

Steele, J. (2016). Episode 40: Literacy and Hawaiian-language newspapers with Kau'i Sai-Dudoit. Retrieved from https://www.hawaiipublicradio.org/post/episode-40literacy-and-hawaiian-language-newspapers-kau-i-sai-dudoit\#stream/0

Ta, V. M., Chao, P. J., \& Kaholokula, J. K. A. (2010). Cultural identity and conceptualization of depression among Native Hawaiian women. AAPI Nexus, 8(2), 63-85.

Teranishi, R. T., Behringer, L. B., Grey, E. A., \& Parker, T. L. (2009). Critical race theory and research on Asian Americans and Pacific Islanders in higher education. New Directions for Institutional Research, 2009(142), 57-68.

Thigpen, R. E. (2012). Teacher responses to participation in Hawaii's Kahua induction program. Retrieved from https://digitalrepository.unm.edu/educ_llss_etds/56 
Tierney, W.G. (1999). Models of minority college-going and retention: Cultural integrity versus cultural suicide. The Journal of Negro Education, 68(1), 80-91.

Tinto, V. (1988). Stages of student departure: Reflections on the longitudinal character of student leaving. The Journal of Higher Education, 59(4) 438-455. Retrieved from https://www.jstor.org/stable/1981920

Trask, H. K. (1999). From a native daughter: Colonialism and sovereignty in Hawai' $i$. University of Hawaii Press.

Umemoto, K., Spencer, J., Miao, T., \& Momen, S. (2012). Disproportionate minority contact in the Hawai ' $i$ juvenile justice system 2000-2010. Final report. Juvenile Justice State Advisory Council and the State of Hawaii, Office of Youth Services.

Uperesa, F. A. L. (2015). Addressing hyper/in-visibility: A roundtable on preliminary research with Pacific Islander student-athletes. Amerasia Journal, 41(2), 67-85.

Vizenor, G. (Ed.). (2008). Survivance: Narratives of native presence. University of Nebraska Press.

White, G. M., \& Tengan, T. K. (2001). Disappearing worlds: Anthropology and cultural studies in Hawai' $i$ and the Pacific. The Contemporary Pacific, 381-416.

Willis, P. E., \& Willis, P. (1981). Learning to labor: How working class kids get working class jobs. Columbia University Press.

Wong, S. S., Sugimoto-Matsuda, J. J., Chang, J. Y., \& Hishinuma, E. S. (2012). Ethnic differences in risk factors for suicide among American high school students, 2009: The vulnerability of multiracial and Pacific Islander adolescents. Archives of suicide research, 16(2), 159-173.

Wright, E. K., \& B. J. N. Balutski. (2016). Ka 'Ikena a ka Hawai'i: Toward a Kanaka 'Ōiwi critical race theory. In Kanaka 'Ōiwi methodologies: Mo'olelo and metaphor, edited by Katrina-Ann Oliveira and Erin Wright, pp. 86-108. Honolulu: University of Hawai i Press.

Wright, E. K. (2003). "Education for the nation": Forging Indigenous Hawaiian identity in higher education (Doctoral dissertation). Retrieved from ProQuest Dissertations and Theses database. (UMI No. 3121160).

Yuen, N. Y., Nahulu, L. B., Hishinuma, E. S., \& Miyamoto, R. H. (2000). Cultural identification and attempted suicide in Native Hawaiian adolescents. Journal of the American Academy of Child \& Adolescent Psychiatry, 39(3), 360-367. 


\section{Appendix A. Coding Guidelines for 'Ike Ma'i'o (Knowledge Content)}

\begin{tabular}{|l|l|l|l|l|}
\hline \multicolumn{1}{|c|}{ 'Āina } & \multicolumn{1}{c|}{ Kūpuna } & \multicolumn{1}{c|}{ Nā Pilina } & \multicolumn{1}{c|}{ Ea } & \multicolumn{1}{c|}{ 'Aha } \\
\hline $\begin{array}{l}\text { E mālama 'ia nā } \\
\text { pono o ka 'āina e } \\
\text { nā ‘ōpio }\end{array}$ & $\begin{array}{l}\text { Na wai ho'i ka 'ole o o } \\
\text { ke akamai, he } \\
\text { alahele i ma'a i ka } \\
\text { hele 'ia e o'u mau } \\
\text { mākua. }\end{array}$ & $\begin{array}{l}\text { 'O ka uhiwai nō kā i ike i ka 'ino o ka } \\
\text { wai. }\end{array}$ & $\begin{array}{l}\text { E ho'ohuli ka lima i } \\
\text { lalo. }\end{array}$ & $\begin{array}{l}\text { 'A'ohe pau ka 'ike i } \\
\text { ka hālau ho'okahi. }\end{array}$ \\
$\begin{array}{l}\text { The traditions of the } \\
\text { land are } \\
\text { perpetuated by its } \\
\text { youth. }\end{array}$ & $\begin{array}{l}\text { Who would not be } \\
\text { wise on a path } \\
\text { walked upon by my } \\
\text { parents and } \\
\text { ancestors? }\end{array}$ & $\begin{array}{l}\text { Only the mist } \\
\text { knows the storm } \\
\text { that caused the } \\
\text { streams to swell } \\
\text { (Pukui }\end{array}$ & $\begin{array}{l}\text { Turn the hands } \\
\text { down. }\end{array}$ & $\begin{array}{l}\text { All knowledge is } \\
\text { not taught in the } \\
\text { same school. One } \\
\text { can learn from } \\
\text { many sources }\end{array}$ \\
\hline
\end{tabular}

\section{Appendix B. The application of 'Ike Ma'i'o to Design of Educational P4}

\begin{tabular}{|l|l|}
\hline 'Ike Ma'i'o & \multicolumn{1}{|c|}{ Application to Design of Educational P4 } \\
\hline 'Āina & $\begin{array}{l}\text { Providing opportunities for experiential learning in the land is a curriculum of } \\
\text { reciprocation, cause and effect, and the impact of praxis (knowledge \& action) on } \\
\text { our immediate environments. }\end{array}$ \\
\hline Kūpuna & $\begin{array}{l}\text { Teaching students the knowledge of their ancestors gives them access to } \\
\text { genealogical legacies, kuleana to master and create new knowledge from multiple } \\
\text { perspectives that challenge the singular narrative. }\end{array}$ \\
\hline Nā Pilina & $\begin{array}{l}\text { Teaching and learning through relationships provides a natural counterbalance to } \\
\text { individualism and meritocracy, while increasing teachers' and students' access to } \\
\text { resources of knowledge production. }\end{array}$ \\
\hline Ea & $\begin{array}{l}\text { When the palms of the hands face down they are occupied and productive, as } \\
\text { opposed to face up when depending on others. This is a curriculum of sustainability } \\
\text { through agency and action. }\end{array}$ \\
\hline 'Aha & $\begin{array}{l}\text { Accessing knowledge through ceremony and protocol as a curriculum allows } \\
\text { access to different schools of knowledge, and can be defined as doing the right } \\
\text { thing, at the right time, for the right reason. }\end{array}$ \\
\hline
\end{tabular}




\section{Appendix C. Coding Guidelines for nā hailona, nā ho'ike a me nā hopena (tests, assessments and outcomes)}

\begin{tabular}{|c|c|c|c|c|c|}
\hline Belonging & Responsibility & Excellence & Aloha & $\begin{array}{l}\text { Total Well- } \\
\text { Being }\end{array}$ & Hawai'i \\
\hline $\begin{array}{l}\text { 'lke aku, 'ike } \\
\text { mai, kōkua aku } \\
\text { kōkua mai; pela } \\
\text { iho la ka nohona } \\
\text { 'ohana. }\end{array}$ & $\begin{array}{l}\text { E hana mua a } \\
\text { pa'a ke kahua } \\
\text { mamua o ke a'o } \\
\text { ana aku ia ha'i }\end{array}$ & $\begin{array}{l}\text { 'A'ohe pu'u } \\
\text { ki'eki'e ke ho‘ā'o } \\
\text { 'ia e pi'i }\end{array}$ & E ‘ōpū ali‘i & $\begin{array}{l}\text { Ua ola loko i ke } \\
\text { aloha. }\end{array}$ & $\begin{array}{l}\text { Ua lehulehu a } \\
\text { manomano ka } \\
\text { ‘ikena a ka } \\
\text { Hawai'i. }\end{array}$ \\
\hline $\begin{array}{l}\text { Recognize and } \\
\text { be recognized, } \\
\text { help and be } \\
\text { helped; such is } \\
\text { family life } \\
\text { (Pukui, 1983, p. } \\
\text { 314). }\end{array}$ & $\begin{array}{l}\text { Build yourself a } \\
\text { firm foundation } \\
\text { before teaching } \\
\text { others (Pukui, } \\
1983, \text { p. 106). }\end{array}$ & $\begin{array}{l}\text { No cliff is so tall } \\
\text { that it cannot be } \\
\text { scaled. No } \\
\text { problem is too } \\
\text { great when one } \\
\text { tries hard to } \\
\text { solve it (Pukui } \\
1983,25) \text {. }\end{array}$ & $\begin{array}{l}\text { Have the heart } \\
\text { of a chief. Have } \\
\text { the kindness, } \\
\text { generosity, and } \\
\text { even temper of } \\
\text { a chief (Pukui, } \\
\text { 1983, p. 129). }\end{array}$ & $\begin{array}{l}\text { Love is } \\
\text { imperative to } \\
\text { one's mental } \\
\text { and physical } \\
\text { welfare (Pukui, } \\
1983, \text { p. } 704) .\end{array}$ & $\begin{array}{l}\text { Great and } \\
\text { numerous is the } \\
\text { knowledge of } \\
\text { the Hawaiians } \\
\text { (Pukui, 1983, } \\
699 \text { ). }\end{array}$ \\
\hline
\end{tabular}




\section{Appendix D. Description of HĀ (BREATH) Indicators}

\begin{tabular}{|l|l|}
\hline $\begin{array}{l}\text { HĀ (BREATH) } \\
\text { Outcomes }\end{array}$ & \multicolumn{1}{|c|}{ Description of HĀ (BREATH) Indicators } \\
\hline Belonging & $\begin{array}{l}\text { Standing firm with a strong foundation of relationships and having an } \\
\text { understanding of lineage and place and a connection to past, present, } \\
\text { and future that allow respectful interactions for the betterment of self and } \\
\text { others. }\end{array}$ \\
\hline Responsibility & $\begin{array}{l}\text { Willingly carrying responsibility for self, family, community and the larger } \\
\text { society while demonstrating a commitment and concern for others } \\
\text { through being mindful of the values, needs and welfare of others. }\end{array}$ \\
\hline Excellence & $\begin{array}{l}\text { A belief that one can succeed in school and life and is inspired to care } \\
\text { about the quality of one's work as demonstrated by a love of learning and } \\
\text { the pursuit of skills, knowledge and behaviors to reach one's potential } \\
\text { while taking intellectual risks and striving beyond what is expected. }\end{array}$ \\
\hline Aloha & $\begin{array}{l}\text { Showing care and respect for self, family, and community through } \\
\text { empathy and appreciation for the symbiotic relationship between all while } \\
\text { building trust and leading for the good of the whole. }\end{array}$ \\
\hline Total Well-Being & $\begin{array}{l}\text { Learning about and practicing a healthy lifestyle while making choices that } \\
\text { improve the mind, body, heart and spirit in order to meet the demands of } \\
\text { school and life while contributing to the well-being of family, 'āina, } \\
\text { community and world. }\end{array}$ \\
\hline Hawai'i & $\begin{array}{l}\text { Being enriched by the uniqueness of this prized place and appreciating its } \\
\text { rich history, diversity and indigenous language and culture in order to } \\
\text { navigate effectively across cultures and communities and be a steward of } \\
\text { the homeland. }\end{array}$ \\
\hline
\end{tabular}




\section{Appendix E. Coding Guidelines for Nā 'Ano o ke A'o 'ana (Characteristics of A'o) Part 1}

\begin{tabular}{|c|c|c|c|}
\hline \multicolumn{4}{|c|}{ Major Characteristic of A'o } \\
\hline \multicolumn{2}{|c|}{ Nalu } & \multicolumn{2}{|c|}{ Hana } \\
\hline \multicolumn{4}{|c|}{$\begin{array}{c}\text { 'Ōlelo No'eau that validates alignment of Major Characteristic of A'o to } \\
\text { Hawaiian Onotological Framework }\end{array}$} \\
\hline \multicolumn{2}{|c|}{ By observing one learns (Pukui 1983, 129). } & \multicolumn{2}{|c|}{$\begin{array}{l}\text { Observe with the eyes; work with the hands. Just } \\
\text { watching isn't enough. Pitch in and help (Pukui } \\
1983,247) \text {. }\end{array}$} \\
\hline \multicolumn{4}{|c|}{ Specific Characteristic of Educational P4 } \\
\hline Active kilo & $\begin{array}{l}\text { Creative application of } \\
\text { 'ike ma'ito to develop } \\
\text { flexibility }\end{array}$ & $\begin{array}{c}\text { Remove doubt } \\
\text { through preparation } \\
\text { and trust in the } \\
\text { process and work of } \\
\text { a'o }\end{array}$ & $\begin{array}{l}\text { Development of depth } \\
\text { of knowledge }\end{array}$ \\
\hline \multicolumn{4}{|c|}{ 'Ōlelo No'eau that validates alignment of Educational P4 to Hawaiian Onotological Framework } \\
\hline $\begin{array}{l}\text { Aia anei ka maka i ke } \\
\text { kua o 'ike 'ole iho? } \\
\text { Are the eyes on the } \\
\text { back that one cannot } \\
\text { see what is being } \\
\text { done? Said of one } \\
\text { who declares that he } \\
\text { doesn't know how to } \\
\text { do a certain thing and } \\
\text { perhaps will not be } \\
\text { able to learn (Pukui } \\
\text { and Elbert } 1983,238) \text {. }\end{array}$ & $\begin{array}{l}\text { Pe'ape'a maka walu } \\
\text { Eight-eyed Pe'ape‘a. } \\
\text { One who is wide awake } \\
\text { and very observant; one } \\
\text { who is skilled. Pe'ape'a } \\
\text { was the son of } \\
\text { Kamehamehanui of } \\
\text { Maui”' (Pukui 1983, } \\
\text { 288). }\end{array}$ & $\begin{array}{l}\text { 'A'ohe 'ulu e loa'a i ka } \\
\text { pōkole o ka lou. } \\
\text { No breadfruit can be } \\
\text { reached when the } \\
\text { picking stick is too } \\
\text { short (Pukui } 1983,25) \text {. } \\
\text { This proverb reminds us } \\
\text { that there is no success } \\
\text { without preparation } \\
\text { (Kahakalau, } 2019, \text { p. } 7 \text { ). }\end{array}$ & $\begin{array}{l}\text { E kuhikuhi pono i na au } \\
\text { iki a me na au nui o ka } \\
\text { ike. } \\
\text { Instruct well in the little } \\
\text { and the large currents } \\
\text { of knowledge. In } \\
\text { teaching, do it well; the } \\
\text { small details are as } \\
\text { important as the large } \\
\text { ones (Pukui 1983, 118). }\end{array}$ \\
\hline
\end{tabular}




\section{Appendix F. Coding Guidelines for Nā 'Ano o ke A'o 'an (Characteristics of A'o) Part 2}

\begin{tabular}{|c|c|c|c|}
\hline \multicolumn{4}{|c|}{ Major Characteristic of A‘o } \\
\hline \multicolumn{2}{|c|}{ Mālama } & \multicolumn{2}{|c|}{ 'Auamo } \\
\hline \multicolumn{4}{|c|}{$\begin{array}{c}\text { 'Ōlelo No'eau that validates alignment of Major Characteristic of A'o to } \\
\text { Hawaiian Onotological Framework }\end{array}$} \\
\hline \multicolumn{2}{|c|}{$\begin{array}{l}\text { E lawe i ke a'o a mālama, a'e 'oi mau ka na'auao. } \\
\text { He who takes his teachings and applies them } \\
\text { increases his knowledge (Pukui 1983, 118). }\end{array}$} & \multicolumn{2}{|c|}{$\begin{array}{l}\text { Ka nui e 'auamo ai i ke keiki i ke kua. } \\
\text { Said of a child about } 10 \text { years old who has grown } \\
\text { big enough to carry a younger sibling on his back. } \\
\text { In ancient days the age of a child was not } \\
\text { reckoned by years but by physical ability to } \\
\text { perform a certain task. }\end{array}$} \\
\hline \multicolumn{4}{|c|}{ Specific Characteristic of Educational P4 } \\
\hline $\begin{array}{l}\text { Extends learning to } \\
\text { and from the home }\end{array}$ & Collaborative A‘o & $\begin{array}{l}\text { Scaffolding or agency } \\
\text { to create readiness }\end{array}$ & $\begin{array}{l}\text { Development and } \\
\text { fulfilment of kuleana }\end{array}$ \\
\hline \multicolumn{4}{|c|}{ 'Ōlelo No'eau that validates alignment of Educational P4 to Hawaiian Onotological Framework } \\
\hline $\begin{array}{l}\text { Ka 'ike a ka makua } \\
\text { he hei na ke keiki. } \\
\text { The knowledge of the } \\
\text { parent is absorbed by } \\
\text { the child (Pukui } 1983 \text {, } \\
\text { p. } 362 \text { ). }\end{array}$ & $\begin{array}{l}\text { Pūpūkahi i holomua. } \\
\text { Unite in order to } \\
\text { progress" (Pukui 1983, } \\
\text { 32). The process of } \\
\text { pooling our strengths } \\
\text { with others to find } \\
\text { solutions to the issues } \\
\text { facing our land and our } \\
\text { people relies heavily on } \\
\text { this concept of } \\
\text { collaboration (Kahakalau, } \\
\text { 2019, p. 6). }\end{array}$ & $\begin{array}{l}\text { Lawe i ka ma'alea a } \\
\text { kū'ono'ono. } \\
\text { Take wisdom and make } \\
\text { it deep" (Pukui 1983, } \\
\text { 211). }\end{array}$ & $\begin{array}{l}\text { He 'ike 'ana 'ia i ka } \\
\text { pono. } \\
\text { It is recognizing the } \\
\text { right thing. One has } \\
\text { seen the right thing to } \\
\text { do and has done it } \\
\text { (Pukui 1983, 98). }\end{array}$ \\
\hline
\end{tabular}

